\title{
POLEMIKA S EXPERTNÍM NÁZOREM NA REGULACI NÁHRADNÍHO MATEŘSTVÍ V ČESKÉ REPUBLICE
}

\author{
KATEŘINA BUREŠOVÁ*
}

\begin{abstract}
The Dispute about Expert Opinions on the Regulation of Surrogacy in the Czech Republic

As a key result of the three-year research project is labelled the expert opinion published in the Journal of Medical Law and Bioethics. The aim of the project was to identify and analyse problems related to surrogacy in Czech legislation. The key result does not take into account many aspects of surrogacy. Some stated opinions seem very problematic and most of them need to be explained or, at least, put to the ray of extensive consideration. This article shows other, polemic opinions with hopes to be noticed as an academic discussion on such an important topic.
\end{abstract}

Keywords: surrogacy; regulation; motherhood; fatherhood

Klíčová slova: náhradní mateřství; regulace; mateřství; otcovství

DOI: $10.14712 / 23366478.2021 .23$

\section{ÚVOD}

Skupina odborníků řešících výzkumný projekt „Náhradní mateřství v ČR: právní, psychosociální a etická analýza“ uveřejnila svoje expertní stanovisko ${ }^{1}$ $\mathrm{k}$ př́ípadné právní regulaci náhradního mateřství v České republice. Výzkumníci tak učinili poté, co se dlouhodobě věnovali tématu náhradního mateřství, jeho problémům souvisejícím s vlastní procedurou a dalším aspektům, přičemž to vše vedlo k status quo „ukotvit nebo zamítnout institut náhradního mateřství v české legislativě“.

Cílem tohoto př́íspěvku je pokračování v odborné diskusi nad otevřenými problémy, nad navrženými směry a výsledky bádání skupiny výzkumníků. Některé totiž vyžadují další, podrobnější komentár a některé dokonce hlubší rozbor, který by mohl ukázat, že výsledky výzkumu, označované za klíčové, nejsou jen černobílé, ale zaslouží ještě další polemiku.

* Autorka je odbornou asistentkou katedry obchodního práva Fakulty právnické Západočeské univerzity v Plzni.

1 KONEČNÁ, H. - CHARAMZA, P. - PRUDIL, L. - RUMPÍK, D. - SVATOŠ, R. Regulace náhradního mateřství v ČR: expertní názor. Časopis zdravotnického práva a bioetiky. 2020, roč. 10, č. 1, s. 14. 
Hned úvodem je nezbytné vyzdvihnout skutečnost, že se výzkumná skupina věnovala dlouhodobě důležitému tématu náhradního mateřství. Celkové uchopení tohoto fenoménu v české společnosti, odborných kruzích a zejména v právním řádu je podhodnocené. A to významně. Ačkoliv by se chtělo vyjádřit názor, že jakékoliv ukotvení náhradního mateřství v legislativě je krokem pozitivním, ba žádoucím, opak může být pravdou.

\section{OBECNÁ ČÁST}

Náhradní mateřství je obecně považováno za velmi citlivé téma. Není bezpochyby ani dostatečně veřejně diskutováno. Pokud ano, spíše v konotacích negativních tehdy, když se objeví ve veřejném prostoru mediálně zajímavá zpráva, kdy v důsledku surogace došlo k nežádoucímu jevu. Např́iklad žadatelský pár dítě odmítl nebo náhradní matka si je nechala, nejhưre je nechtěl nikdo, protože se narodilo se zdravotním hendikepem. Tyto př́pady sice na chvíli pozvednou veřejnou diskusi o náhradním mateřství, ale vede se špatným směrem. Zpravidla totiž náhradní mateřství ve svém důsledku odmítají jako něco špatného, nevhodného nebo nemorálního. O povedených surogacích, fungujících rodinách dětí počatých náhradní matkou, naplněných snech rodičů se veřejné diskuse nevedou a média o nich žádné zajímavé př́iběhy nepřináší. To pak samozřejmě vede k tomu, že názory ve společnosti jsou laděné negativně, když jediná zkušenost $\mathrm{s}$ náhradním mateřstvím je spojená $\mathrm{s}$ jeho negativními následky.

Odborná právní diskuse o surogátním mateřství ale probíhá již několik let. ${ }^{2}$ A zarážející je, že expertní stanovisko jako by ji vůbec nezohledňovalo, názory jiných odborníků nebralo v potaz a nepolemizovalo s nimi. Výzkumníci prostě vycházejí z vlastních závěrů a nelze se oprostit od dojmu, že jsou vedeni vlastními morálními hodnotami více než odbornými názory publikovanými ve veřejném prostoru. Na druhou stranu je však toto přirozené, lidské hledisko pochopitelné a u tématu náhradního mateřství i očekávatelné.

Skupina expertů, jejichž závěry jsou východiskem následující polemiky, je tvořena 10 lidmi $^{3}$ dlouhodobě se zabývajícími náhradním mateřstvím. Z nich celá polovina se náhradním mateřstvím zabývá profesně a procedura jim přináší nějaký zisk, což je staví do střetu zájmů s výsledky jejich zkoumání. Jednoduše mají zájem na určité formě regulace, resp. mohou z ní pro ně plynout nějaké výhody a jejich odborný názor jimi může být zastíněn.

Východiskem pro vytvoření expertního názoru na náhradní mateřství je konstatování o tom, že procedura náhradního mateřství vytlačuje zájem o osvojení, a to, že naše země je vyhledávanou destinací pro pacienty z celého světa, což má být důvodem potřeby legislativního ukotvení. Nade vši pochybnost souhlasím s nutností konečně se vypořádat s existencí této formy asistované reprodukce a s jejími konsekvencemi v podobě

2 Např. KRÁLIIČKOVÁ, Z. Mater semper certa est! O náhradním a kulhajícím mateřství. Právní rozhledy. 2015, roč. 23, č. 21, s. 725-732; nebo BUREŠOVÁ, K. Surogátní mateřství a jeho (nejen) právní aspekty. Právní rozhledy. 2016, roč. 24, č. 6, s. 193-201.

3 Tým tvoří dva lékaři poskytující asistovanou reprodukci, čtyři právníci, dvě psycholožky, sociální pracovnice a etik. 
vytvoření právní regulace. Ovšem ne proto, že by snad vzrůstal počet dětí narozených prostřednictvím náhradní matky. Ale proto, že všichni zúčastnění, tj. náhradní matka (potažmo její partner, manžel), zamýšlení rodiče (single rodič), dítě (plod) a v neposlední řadě i klinika poskytující asistovanou reprodukci, by měli mít zcela jasno o celém procesu, jeho důsledcích a jejich rolích včetně jejich právního postavení. Epicentrem všeho pak je dítě (plod), které samozřejmě o vlastním právním postavení nemá nejmenší ponětí, ale musí být zvláště chráněno a jeho práva a postavení $\mathrm{v}$ procesu musí regulace jasně stanovit. $V$ př́padě potřeby tu jsou již dnes př́islušné orgány, které zajišt'ují, aby jeho nejlepší zájem byl předním hlediskem celého procesu a jeho následků.

\section{REGULACE VS. ZÁKAZ PROCEDURY}

Tři experti zastávají názor, že by náhradní mateřství mělo být zcela zakázáno. Další odborník měl tentýž názor, ale má za to, že takový zákaz není celospolečensky průchozí, proto se nakonec vyslovil pro regulaci. Tato skutečnost je klíčová, protože názor $40 \%$ skupiny vede $\mathrm{k}$ zákazu náhradního mateřství, a pak zcela postrádá smysl klást další otázky spojené s návrhy na konkrétní opatření při regulovaném stavu. Podle názoru jednoho z dotazovaných je institut náhradního mateřství komercializován a je užíván i tehdy, existují-li alternativní řešení situace. Poukazuje na neexistenci vzorového řešení, které by bylo přijatelné. Zde totiž odkazuje na změny, které legislativu náhradního mateřství provází v jiných státech. „Irsko, které zákon vytváří, se inspiruje NL, které má př́sné podmínky. NL ale pokukuje po zákonech UK, kde jsou podmínky volnější. UK, kde je náhradni mateřství momentálně na cestě ke změně zákona (plánováno na 2021), pokukuje po Kalifornii, kde je to oficiálně komerční procedura pro kohokoliv. Indie a dalši asijské státy, které měly velmi propracovaný komerčni systém, před dvěma lety změnily zákony na velmi restriktivní, protože se to rozvinulo v neudržitelný obchod se ženami a dětmi. "4

Kvituji s povděkem, že skupina expertů je seznámena se zahraničními úpravami. Zcela jistě by česká cesta neměla být vymýšlena od základu na zelené louce, ale měla by se inspirovat př́klady dobré praxe. Je však třeba srovnávat srovnatelné a využívat zkušeností, jež jsou v našich podmínkách dosažitelné. Asijská surogační turistika byla v minulosti proslulá. Př́iliš otevřený systém, v němž nepanovala žádná striktní pravidla. Hlavní roli v něm hrály peníze. Postupně však vyplouvaly na povrch problémy, které nejen z morálních důvodů nebylo možné nadále přehližet. Jeden př́ílad za všechny. Do Thajska přicestoval australský manželský pár s cílem nalézt náhradní matku, která by mu odnosila dítě. V sedmém měsíci těhotenství náhradní matka zjistila, že chlapec, kterého společně s holčičkou nosí, bude velmi pravděpodobně trpět Downovým syndromem. Náhradní matka z důvodu svého vyznání odmítla podstoupit potrat dítěte, který navrhoval australský manželský pár. Po porodu obou dětí si australský pár osvojil pouze holčičku a chlapce $\mathrm{s}$ Downovým syndromem ponechal v péči náhradní matce, která byla současně právní matkou. Náhradní matka neměla na péči o dítě se specifickým

4 KONEČNÁ - CHARAMZA - PRUDIL - RUMPÍK - SVATOŠ, $c . d$. 
postižením finanční prostředky, a protože nevěděla, jak se o dítě, které mělo vyrůstat v Austrálii, postarat, případ medializovala. ${ }^{5}$ Tento př́běh, jakož i prríběhy vykořist'ovaných indických žen, vyústily ve změnu tamních legislativ, které nezměnily komerční charakter náhradního mateřství, ale vyloučily, aby se o tento typ asistované reprodukce ucházeli zahraniční rodiče. Nelze tedy odhlížet od faktu, že velký význam na negativní konotaci náhradního mateřství, tedy na postavení náhradních matek, má jejich socioekonomické postavení. Dalším problémem pak je nedostatečná úprava podmínek náhradního mateřství, kdy není, mimo jiné, vyjasněno právě ono rozhodování o plodu nebo přinejmenším není předem vyjasněno, za jakých okolností může zamýšlený rodičovský pár od osvojení dítěte ustoupit a za jakých může naopak náhradní matka od dohody celé odstoupit, tj. ponechat si dítě v péči. Situací může nastat celá řada. Je nezbytné nad nimi vést diskusi, protože jich právě již taková řada nastala, některé i u nás, jak dobře mimo jiné ilustruje i zmiňovaný projekt „Náhradní mateřství v ČR: právní, psychosociální a etická analýza".6

Pokud se Česká republika vydá směrem k zákazu náhradního mateřství, pak se experti podporující tuto cestu shodují i na tom, že by náhradní mateřství podstoupené českými občany v zahraničí posuzovali stejnou optikou a dítě pocházející z náhradního mateřství uskutečněného v zahraničí a dovezené do České republiky jako dítě osvojené českými občany by měli za dítě pocházející z trestné činnosti - obchodu s dětmi.

Toto je velmi nebezpečná premisa, která by v moderním světě otevřených hranic, sdílení hospodářského prostoru a dalších významných hodnot neměla být vůbec na stole. Jednak by na každé osvojení realizované v cizině mohlo být nazíráno jako na trestné, vyžadující řádné vyšetření okolností osvojení. K tomu je zcela nezbytné zdůraznit, že experty navrhované vrácení dítěte do země narození, resp. umístění jej do náhradní rodinné péče, již překračuje hranice nejlepšího zájmu dítěte, kterému by po př́ijezdu do České republiky úruady okamžitě odebraly statut dítěte konkrétních rodičů a umístily je do ústavu s nejistou vyhlídkou rodinné péče vůbec. Stanovisko expertů přehlíží i stávající právní úpravu uznání rozhodnutí vydaného cizím státem ve věci osvojení, podle níž se takové rozhodnutí uzná tehdy, nepř́ićí-li se veřejnému pořádku a nebrání-li tomu výlučná pravomoc českých soudů a osvojení by bylo př́ípustné i podle hmotněprávních ustanovení českého práva. ${ }^{7} \mathrm{~V}$ tomto kontextu je pak zajímavý nález Ústavního soudu, v němž mimo jiné vyslovil závěr, že ,neuznání cizího rozhodnutí, kterým bylo určeno rodičovstvi $k$ ditéti dvou osob stejného pohlaví v situaci, kdy už rodinný život byl mezi nimi fakticky i právně konstituován formou náhradního mateřství, z diovodu, že české právo neumožňuje rodičovství dvou osob stejného pohlaví, je v rozporu s nejlepším zájmem ditěte ". 8 Ústavní soud nepodrobil zkoumání proceduru náhradního mateřství jako takového, ale zabýval se otázkou nejlepšího zájmu dítěte v již existujících a funkčních vztazích.

5 Např. Thailand bans commercial surrogacy for foreigners. In: BBC NEWS [online]. 20. 2. 2015 [cit. 2016-01-06]. Dostupné na: http://www.bbc.com/news/world-asia-31546717.

6 Viz KONEČNÁ, H. - SVATOŠ, R. Sdílená odpovědnost v proceduře náhradního mateřství. Časopis zdravotnického práva a bioetiky. 2018, roč. 8, č. 3, s. 54-67.

7 Srov. § 63 zákona č. 91/2012 Sb., o mezinárodním právu soukromém.

Nález Ústavního soudu ze dne 27. 6. 2017, sp. zn. I ÚS 3216/16. 
Je nanejvýše zajímavé, že akceptování zahraničních procedur schvalují jen tři respondenti. Přitom současná takřka žádná právní regulace náhradního mateřství žádné takové omezení ve vztahu k zahraniční surogaci nestanoví. To znamená, že v praxi se řada rodičů obrací právě na zahraniční kliniky a absolvuje proceduru tam, kde regulace je, a tuto bez dalšího dodržují. Je jim pravděpodobně bližší projít náhradním mateřstvím při existenci právního rámce než se pohybovat $\mathrm{v}$ šedé zóně zákona $\mathrm{v}$ domácích podmínkách. To by se mělo do budoucna změnit $v$ jejich neprospěch? Chceme skutečně jít cestou, kdy budeme nahlížet dvojím metrem na statusové vztahy? Domnívám se, že to není udržitelný postoj. Zvažme totiž, že řada rodičů může být tvořena smíšenými páry, kdy jeden z páru může být cizinec. Pak by asi náhradní mateřství podstoupit v cizině mohli? Ale jejich sousedé, bohužel pár Čechů, by stejnou možnost neměl, jejich dítě by bylo považováno za jimi unesené $\mathrm{v}$ cizině? Považme jen, zda by se k nám nebáli přicestovat cizinci, jejichž děti byly počaty právě surogační procedurou. ${ }^{9}$

K zavedení centrálního posuzování a schvalování každé procedury náhradního mateřství se vyslovili všichni experti. Bylo konstatováno, že panuje shoda na procesu schvalování a kontrolovatelnosti náhradního mateřství centralizovanou formou.

V otázce schvalování se nabízí dvě alternativy. Jedna je zavedení centrálního schvalování nezávislou komisí, protože nelze takový akt ponechat $\mathrm{v}$ rukou jediného rozhodujícího. Druhá je stanovit jasné podmínky a jejich splnění nechat na aplikační praxi garantované akreditovaným centrem asistované reprodukce. Takové centrum by muselo kromě odpovědnosti za splnění podmínek být i garantem celé řady souvisejících úkonů včetně poskytování psychologické, medicínské, právní a jiné pomoci.

\section{ŽADATELÉ}

Žadatelem se v souvislosti s debatou nad náhradním mateřstvím rozumí osoba, která se má stát rodičem dítěte počatého náhradní matkou. Otázka žadatelů je opět značně rozporuplná, protože žadatel může být jediná osoba, pár nestejnopohlavní, pár stejnopohlavní, pár sezdaný, pár nesezdaný atp.

Stanovisko výzkumné skupiny lpí na heterosexuálních párech, spíše se přiklání k tomu, aby byly sezdané. Bez výjimky vylučují single žadatele a stejnopohlavní páry. Doporučují limitaci věkovou hranicí, přinejmenším kopírujíce věkové podmínky stanovené zákonem o specifických zdravotních službách, ne-li snižovat hranici u žen na 40 let věku.

Je třeba zde opět klást otázky a vést hlubší diskusi. Připustíme-li žadatele pouze jako sezdaný pár, co tím získáme? Představuje sezdaný pár větší jistotu stabilního prostředí pro výchovu dítěte? Odpovědí může být skutečnost, že soudci Ústavního soudu došli k závěru, že manželství představuje vyšší míru stability vztahu, a tím i vhodnějšího prostředí pro výchovu dítěte a zejména jeho lepší zajištění v př́padě ukončení soužití

9 Podobná situace nastala při hledání sídla jednoho unijního úřadu. Vytipováno bylo vhodné místo v Budapešti. Nicméně zaměstnanci toto striktně odmítli, nebot' mad’arské zákony jsou vůči LGBT osobám velmi nevstřícné a panovala obava, že by rodinné vazby založené v zahraničí nebyly v Mad'arsku akceptovány. 
rodičǔ. ${ }^{10}$ Jak soudci Ústavního soudu, tak i členové expertní skupiny, kteří vydali stanovisko k regulaci náhradního mateřství, se nedůvodně zaštit'ují domnělou stabilitou představovanou institutem manželství a s ním bezprostředně související lepší ochranou zájmů dítěte. Ovšem bez jakéhokoliv racionálního vysvětlení a při absenci zamyšlení se nad realitou, v níž je takřka každé druhé manželství rozvedeno a statistika stability vztahů konkubinátních pro porovnání neexistuje a statistika jiných je zpravidla úmyslně přehlížena. Jsme-li u těch jiných vztahů, nutno zde doplnit, že partnerské vztahy gayů a leseb stabilnost vykazují, nebot' podle dostupných údajů činí zrušená partnerství zhruba $14 \%$ všech uzavřených partnerství. ${ }^{11}$ Přesto tyto vztahy nejsou za stabilní považovány, ne tedy z hlediska výchovy dětí.

Vrat'me se ale k oné domnělé vhodné stabilní rodinné konstelaci, kterou experti shodně se soudci Ústavního soudu preferují. Zde by totiž bylo namístě vzít v úvahu i stanovisko odborníků v oblasti rodiny a výchovy dětí a upřednostnit je na úkor vlastních hodnot a morálně tendenčních předsudků. $Z$ hlediska práva pak nelze vystihnout srovnání rodinné péče podmíněné sezdáním rodičů lépe než v disentu výše odkazovaného rozhodnutí Ústavního soudu. ${ }^{12} \mathrm{Z}$ hlediska jiných vědních oborů nelze přehlížet stanoviska odborných platforem $\mathrm{k}$ výchově dětí stejnopohlavními páry, ${ }^{13}$ která se jednoznačně shodují na tom, že taková výchova není ničím odlišná od výchovy různopohlavním párem a děti vyrůstající v homoparentálních rodinách netrpí v žádném aspektu. Nemohu si odpustit připomenout, že procedura náhradního mateřství je velmi dlouhá, čítá řadu měsíců. A vztahy a svazky žadatelů na jejím počátku nemusí nutně vydržet až do jejího konce. S tímto aspektem bychom měli počítat a měli bychom na něj být také připraveni. Je navíc důvodem, proč je nesmyslné zabývat se otázkou statusového postavení žadatelů, když se jedná o kategorii v čase proměnnou.

Polemika nad národností žadatelů nepřinesla v rámci panelu shodu. Část expertů se přiklání k tomu, aby žadatelé byli občany ČR, pokud ne, pak aby měli na území ČR alespoň trvalý pobyt. Osobně bych tuto kategorii rozšsiřila nejméně na př́slušnost unijní,

10 Rozhodnutí Ústavního soudu ze dne 19. 11. 2015, sp. zn. Pl. ÚS 10/15.

11 Neexistenci oficiální statistiky nahrazuje vlastní sledování aktivisty Mildy Šlehofera (od roku 2017 ve sběru pokračuje Jan Fiala), který uvádí, že do konce roku 2016, tedy za 10 let existence zákona o registrovaném partnerství, do registrovaného partnerství vstoupilo 2510 osob a zrušených partnerství bylo 369 (FIALA, J. - KROPÁČEK, J. - POLÁK, M. Registrovaná partnerství fungují přes deset let: kolik párů si řeklo ano, kolik rozvedlo. In: Aktuálně.cz [online]. 11. 2. 2017 [cit. 30. 4. 2021]. Dostupné na: https:// zpravy.aktualne.cz/domaci/grafika-registrovana-partnerstvi/r 5fb3d54aec4811e6b0800025900fea04/? redirected=1539182830). Data až do roku 2018 uvádějí 3117 uzavřených a 448 ,rozvedených“ (FIALA, J. KOMPLET-Registrovane-partnerstvi-Jan-Fiala [nepublikovaná data]. Praha, 2019).

12 Disent k Rozhodnutí Ústavního soudu ze dne 19. 11. 2015, sp. zn. Pl. ÚS 10/15.

13 Např. Kanadská asociace psychologů (Canadian Psychological Association / Société Canadienne de Psychologie. Marriage of Same-Sex Couples - 2006 Position Statement Canadian Psychological Association [online]. 2006 [cit. 30. 4. 2021]. Dostupné na: https://web.archive.org/web/20090419195945/http:// www.cpa.ca/cpasite/userfiles/Documents/Marriage\%20of\%20Same-Sex\%20Couples\%20Position\%20 Statement \%20-\%20October\%202006\%20\%281\%29.pdf); Americká akademie pediatrů (PERRIN, E. C. - SIEGEL, B. S. - the Committee on Psychosocial Aspects of Child and Family Health. APA Promoting the Well-Being of Children Whose Parents Are Gay or Lesbian. Pediatrics [online]. 2013, Vol. 131, No. 4, s. 1374-1383 [cit. 2021-05-17]. Dostupné na: https://doi.org/10.1542/peds.2013-0377); Americká asociace psychologů (American Psychological Association. APA RESOLUTION on Sexual Orientation, Gender Identity (SOGI), Parents and their Children [online]. 2020, s. 1-7 [cit. 2021-05-17]. Dostupné na: https:// www.apa.org/about/policy/resolution-sexual-orientation-parents-children.pdf). 
tj. na př́slušnost nebo trvalý pobyt $\mathrm{v}$ kterémkoliv členském státě. Je zcela namístě zabývat se problémem surogátní turistiky. Nicméně i s ohledem na fakt, že na tuzemských klinikách asistované reprodukce je poskytována péče zahraničním klientům, bych u žadatelů o náhradní mateřství nepodmiňovala jejich nárok př́islušností k České republice, ale $\mathrm{v}$ rámci řady sdílených hodnot př́slušností unijní.

Důvod, který má vést $\mathrm{k}$ možnosti využít náhradní mateřství, je jednohlasným stanoviskem expertů medicínského charakteru. Ve velké většině př́ípadů takové pravidlo určitě má platit. Náhradní mateřství by nemělo sloužit jako obchod s dětmi, ale mělo by mít relevantní důvod. Proto se stejně jako panel expertů přikláním $\mathrm{k}$ tomu, že by měl být vybudován systém odborných poradenských míst, v nichž žadatel kromě detailního seznámení s procedurou obdrží všechny informace a poučení charakteru právního, psychologického a zdravotního. Kromě toho by měl žadatel podstoupit psychologické vyšetření obdobné vyšetření, jemuž jsou podrobeni žadatelé o osvojení. Rozhodně vhodné by bylo posoudit žadatele i z dalších hledisek, tj. jejich finanční situace, zázemí, trestní rejstř́ik. Rozhodnutí, zda žadatele k proceduře připustit, by měl učinit $\mathrm{k}$ tomu určený orgán po získání komplexních informací. Lze zde uvažovat o orgánu sociálně-právní ochrany dětí jako obdoby procesu osvojení, resp. hodnocení uchazečů o náhradní péči o děti.

\section{NÁHRADNÍ MATKA}

Žena, která podstupuje náhradní mateřství s tím, že odnosí dítě a udělí souhlas $\mathrm{s}$ jeho osvojením ve prospěch někoho jiného, musí splňovat řadu předpokladů. Jednak musí být zdravá a schopna početí a donošení dítěte. Musí být psychicky odolná nejen pro zvládnutí těhotenství, ale též pro následný proces osvojení dítěte, které porodí. Její statusové postavení není relevantní, shodují se takřka všichni experti. Nelze než souhlasit, nebot' je to opět proměnlivá skutečnost a nemůže nikdo ženě zabránit, aby se v průběhu těhotenství, odhlédneme-li od neplánovaných událostí, jako je smrt jejího protějšku, provdala, rozvedla apod. Úplný konsenzus padá na zkušenosti s těhotenstvím a mateřstvím. Ty by náhradní matka měla mít.

Kromě výše uvedených aspektů se experti ještě vyjádřili $\mathrm{k}$ věku náhradní matky. Hranicí má být hranice plodnosti, tj. 49 let, kterou by někteř́ ještě snížili až na 40 let. Tématem $\mathrm{k}$ diskusi je možný počet dětí, které pro jiné náhradní matka může donosit. Zde se rozhodně přikláním $\mathrm{k}$ tomu, aby takový počet nebyl nijak velký, protože náhradní matka by měla být nejvíce vedena altruistickými myšlenkami podstoupit proceduru, a tyto lze jistě vyčerpat donošením počtu dětí v řádech jednotek, blížícímu se spíše jednomu. Na druhou stranu lze správně polemizovat, že náhradní matka, která již proceduru podstoupila a naplnila tak přesně obsah dohody s žadateli, je vhodná kandidátka. Navíc počet žen v naší zemi, které by byly schopné stát se náhradní matkou, nebude moc vysoký. Každopádně by náhradní matka před započetím procesu měla projít obdobným vyšetřením jako žadatelé, tj. jednak by měl být posouzen její zdravotní stav, psychický stav a obecně její zázemí. Na rozsahu nezbytných vyšetření a posudků se sice experti v rámci řešeného projektu náhradního mateřství neshodli, ale tato diskuse zcela 
jistě vyžaduje širší panel a názorové spektrum. Osobně bych byla přísnější a měla bych za to, že tato žena by skutečně měla být podrobena řadě odborných vyšetření, měl by jí být poskytnut právní servis a podpora psychologa. Důležité je také to, jak tito odborníci se ženou zacházejí, protože to nemá být vedeno s cílem ženu odradit, ale zjistit, zda je vhodnou adeptkou, a pomoci jí se v celé situaci zorientovat a ujasnit si všechny její aspekty a dopady do jejího života a života její rodiny. Důležité je i zázemí této ženy, nebot' při komplikacích spojených s těhotenstvím musí mít žena možnost bez obavy o péči o svoji rodinu nebo její finanční zabezpečení pečovat o sebe a o plod, který nosí.

Zajímavý je požadavek většiny expertů na existenci vztahu mezi náhradní matkou a žadateli, který by přinejmenším měl být na bázi „dobré známosti“, ne-li přímo příbuznosti. Tady se opět přikláním k menšině. Nedomnívám se, že by nutně měl vztah mezi dotčenými osobami existovat. U př́ibuzných je taková situace často pochopitelná, připomeňme, že vlastně jediná zmínka v občanském zákoníku ${ }^{14}$ týkající se náhradního mateřství je právě z důvodu této eventuality a řeší príbuzenské vztahy mezi náhradní matkou a žadatelkou ve smyslu umožnění osvojení dítěte, jež by jinak bylo považováno za príbuzného v takovém postavení, které osvojení vylučuje. V mnoha príípadech si ale dokáži představit, že náhradní matka se bude od dítěte raději distancovat, aby zachovala svou altruistickou intenci, a častý styk s dítětem by pro ni mohl být z psychického hlediska nežádoucí. Proto bych byla v podmínce „dobré známosti“ spíše zdrženlivá.

\section{GAMETY A EMBRYA}

Bez výjimky panuje shoda panelu na původu gamet. Mají pocházet od žadatelů. Nelze zde nevidět nejméně dva problémy. Jednak se tímto vylučují zdravotně nezpůsobilí žadatelé, ačkoliv právě to je zjevně důvod, který je k asistované reprodukci vůbec přivedl. Jednak tím vyloučíme i osoby, které $z$ důvodu přenosu dědičných chorob nemohou nebo nechtějí vlastní gamety využít. Druhý problém je v tom, že požadavek vlastních gamet může vést $\mathrm{k}$ vyloučení stejnopohlavních párů.

Důsledky rozhodnutí o podmínkách původu gamet mají dopad i na právo znát své rodiče, totiž i ty genetické. Na tomto aspektu v odborných diskusích rozhodně nepanuje žádná shoda. Na jedné straně je právo dítěte znát svůj původ a s ohledem na emoční a zdravotní důvody to je relevantní. ${ }^{15} \mathrm{Na}$ druhé straně může docházet $\mathrm{k}$ tomu, že dárců, tj. osob ochotných darovat genetický materiál, může ubývat, protože o styk s dítětem nestojí a celou procedurou neprochází proto, aby zplodili dítě, s nímž naváží vztah, ale proto, aby pomohli jiným lidem $\mathrm{v}$ jejich nenaplněném životním snu. Netroufám si zde vyřknout jednoznačnou podporu pro tu kterou variantu, nebot' bych za správné považovala stanovisko povolanějších profesí.

Při respektování práva znát svůj původ ve smyslu Úmluvy o právech dítěte bychom měli ale souvztažně řešit styk dítěte a náhradní matky, potažmo muže, který daroval sperma. Zde jsou ale experti skupiny zdrženliví, když de facto nepřipouští použít cizí

\footnotetext{
14 § 804 zákona č. 89/2012 Sb., občanský zákoník.

15 Právo znát svůj původ, je-li to možné, garantuje Úmluva o právech dítěte v článku 7.
} 
genetický materiál. Omezují nicméně nepřímo okruh osob, které se mohou prostřednictvím náhradního mateřství stát rodiči na osoby zdravé, kde se poněkud ztrácí význam procedury, protože zpravidla dokáží zplodit dítě bez asistované reprodukce nebo prostřednictvím její jiné formy. At' tak či tak, nezapomínejme, že i dítě by mělo o takový styk projevit zájem, než ho společnost bude nutit, a jak mu v útlém věku vysvětlit složité vazby a zajistit styk např́klad na dálku, jsou jen první z celé řady dodatečných otázek, na něž nemáme uspokojivou odpověd’.

\section{PRÁVNÍ ASPEKTY}

Bezpochyby tím nejdůležitějším momentem je rozhodnout, kdo bude matkou dítěte. Otec zde není na prvním místě jednoduše proto, že jeho otcovství k dítěti lze řešit již v průběhu těhotenství náhradní matky. Nicméně i právě proto je z mého pohledu zcela namístě uzavřená písemná dohoda mezi žadateli a náhradní matkou, která kromě závazku náhrady vynaložených nákladů upravuje i způsob početí, použití gamet (vlastních či dárcovských), řešení nastalých situací (kdo rozhoduje o případném přerušení těhotenství, kdo bude u porodu...), prohlášení o otcovství (zřejmě na základě domněnky svědčíí ve prospěch muže, jenž dal k umělému početí souhlas) atd. Písemná dohoda má nicméně relativní povahu, jež ve svém důsledku může vést ke značné nejistotě spočívající ve vymahatelnosti závazků, a koreluje tedy se stávajícím „bezpečným“ “ řšením ve smyslu mater sempre certa est. ${ }^{16}$

Vrat'me se tedy zpět k mateřství. Současná právní úprava bezvýjimečně uznává jako matku dítěte ženu, která dítě porodí. Přesto se v diskusích setkáváme i s nastolením problému, zda by jí neměla být žena, která poskytla biologický materiál, tj. biologická matka. ${ }^{17} \mathrm{~K}$ udělení souhlasu s osvojením ze strany matky může dojít až po narození dítěte. Zde může ale takto dospět představa o dítěti a rodičovství do zcela jiných konotací. Nikoliv nevýznamnou roli budou hrát emoce. Co když náhradní matka nesvolí s osvojením nebo svůj souhlas odvolá? Co když se žadatelům nebude dítě líbit? Co když dítě bude fyzicky nebo psychicky postižené a nebude o ně zájem na žádné straně? Těmto tíživým situacím by prospěla právní jistota, zejména by pak prospěla dítěti, resp. nascituru. Nemohu než se prriklonit $\mathrm{k}$ tomu názoru, že není vhodné připustit změnu rozhodnutí žádné ze zúčastněných stran. Rodičovská práva by podle mého názoru měla být na žadatelích již od okamžiku prokázání existence živého prosperujícího plodu, bez ohledu na to, jak účelně to vypadá. Díky tomu by totiž odpadly výše naznačené otázky a jejich řešení. Rovněž by bylo postaveno najisto, kdo a od jakého okamžiku může čerpat rodičovskou dovolenou, kam dítě přihlásit $\mathrm{k}$ trvalému pobytu, která zdravotní pojišt'ovna bude hradit náklady na léčbu dítěte, kdo bude rozhodovat o poskytnutých zdravotních službách atp. Doplním pak ještě, že i souhlas s osvojením udělený matkou bude narážet na existenci manželství mezi žadateli, a je třeba tedy tento

16 KRÁLÍČKOVÁ, Z. - HRUŠÁKOVÁ, M. - WESTPHALOVÁ, L. a kol. Občanský zákoník. II., Rodinné právo (§ 655-975): komentáŕ. 2. vyd. Praha: C. H. Beck, 2020.

17 MITLÖHNER, M. Vybrané otázky náhradního mateřství. Rodinné listy. 2013, roč. 2, č. 12, s. 2; nebo VACOVÁ, R. Náhradní mateřství a postavení biologického rodiče. Právo a rodina. 2020, roč. 22, č. 2, s. 12. 
aspekt vzít v úvahu tehdy, pokud připustíme, že manželství nemusí vydržet po celou dobu těhotenství a dítě již v jeho průběhu ztrácí jednoho rodiče a potenciální ekonomickou stabilitu. Názor na trvalost vztahů založených dohodou mezi náhradní matkou a žadateli bude $\mathrm{v}$ platném právním rrádu narážet na nezadatelnou povahu statusových práv. Rovněž bude sama dohoda významně kolidovat s principy rodinného práva, které u nás tradičně neumožňuje uzavírání podobných závazků, nepřipouští možnost vlastní úpravy práv a povinností ve vztahu k dětem a zejména odmítá, že by se člověk mohl stát předmětem smlouvy. ${ }^{18}$ Narušit takovou koncepci a povahu dlouhodobě uplatňovanou není bez dalšího možné, vyžaduje důkladnou odbornou diskusi. ${ }^{19}$

\section{KOMPENZACE}

Problém úplaty náhradní matce za odnošení dítěte by skupina řešila bud' prostřednictvím paušálu, nebo doložitelných nákladů, což je preferovaný způsob. Stanovení paušálu nepovažuji za ideální řešení, náklady se mohou různit. Zdravotním stavem a nutností přidružené léčby, náhradou ušlého zisku, když bude náhradní matka ve stavu neschopnosti vykonávat svoji běžnou pracovní činnost, náklady běžné se mohou v různých částech země výrazně lišit, navíc berme v potaz individuální povahu každé ženy a její vlastní hospodářské úsudky. Zde je totiž namístě již výše zmiňovaná dohoda mezi náhradní matkou a potenciálním rodičem, v níž by bylo možné i tuto otázku uspokojivě vyřešit. Pokud by navíc dohoda podléhala supervizi, bylo by i vyloučeno, aby náhradní matka získala víc než jen náhradu nákladů. A to je přece to, oč zde nejvíce jde.

\section{VYHLEDÁNÍ NÁHRADNÍ MATKY}

Č́st skupiny se v otázce osoby náhradní matky přiklání pouze ke vzoru př́buzná či známá a vylučuje oslovení cizí ženy. Nicméně část skupiny uvažuje o možnosti inzerce a pomoci specializovaných organizací, at' už komerčních, či neziskových. I já zde preferuji fungování odborných organizací, které kromě řady dalších úkolů budou nápomocny vyhledání vhodné náhradní matky. Nezisková organizace může narážet na omezené finanční prostředky, a tedy i omezené možnosti pomoci. Komerční společnost může poskytovat odborné služby na vysoké úrovni, které zase nebudou obecně dostupné $\mathrm{z}$ hlediska úplaty. Přesto bych v nich viděla potenciál, který by dokázal poskytovat vysoký standard služeb, nebot' umožnění fungování komerční agentuře by mělo být vázáno na předem stanovená pravidla a povolení by bylo možné odejmout, kdyby měl jejich standard kolísavou úroveň.

18 KRÁLÍČKOVÁ, $c$. $d$.

19 Na změny v prủběhu celého procesu upozorňuje již v roce 2015 článek CÍSAŘOVÁ, D. - SOVOVÁ, O. Náhradní mateřství v právní praxi. Časopis zdravotnického práva a bioetiky. 2015, roč. 5, č. 2, s. 13-24. 


\section{ZÁVĚR}

Bylo položeno mnoho velmi zásadních otázek a expertní stanovisko $\mathrm{k}$ nim nevyslovuje žádný názor. Naopak lze též konstatovat, že vyřčená expertní stanoviska nejsou dogmatem a přispívají do širší diskuse. Je ale nezbytné, aby byla opřena o další hlubší rozbor, vysvětlení.

Aktuálně v České republice náhradní mateřství probíhá, dochází $\mathrm{k}$ němu. Všichni zúčastnění se pohybují v šedé zóně zákona, ale touha po dítěti je natolik silným motivátorem, že nežádoucí aspekty procesu úmyslně opomíjí a nechávají stranou. Dokonce zde vzniká advokátní specializace, kdy některé kanceláře poskytují právní servis v oblasti náhradního mateřství a radí, jak se v aktuální legislativě pohybovat. Takový stav nelze považovat za žádoucí. Rozhodnutí o regulaci a zejména její zpracování je zcela nevyhnutelné. Volají po tom i podobná expertní stanoviska ${ }^{20}$ a měla by být vyslyšena. Ved'me však otevřenou a multinázorovou diskusi nad jednotlivými aspekty regulace, at' se vydáme dobrou cestou a nevytváŕíme zbytečně prekážky něčemu, co zde stejně bude existovat a bude působit následky v právním postavení zúčastněných osob.

JUDr. Kateřina Burešová, Ph.D.

Právnická fakulta Západočeské univerzity v Plzni

kburesov@fpr.zcu.cz

20 Např. CÍSAŘOVÁ - SOVOVÁ, $c$. $d$.; nebo KRÁLÍČKOVÁ, $c$. $d$.; nebo FOREJTOVÁ, M. - BURIÁNOVÁ, P. Náhradní mateřství a otazníky, které ho doprovázejí (1.). Rodinné listy. 2018, roč. 7, č. 7, s. 17-23. 